\title{
The Paths of Islamism in Contemporary Islam: A Theoretical Re-Analysis
}

\author{
Antonello Canzano \\ University “G. d'Annunzio" of Chieti-Pescara, Pescara, Italy \\ Email: a.canzano@unich.it
}

How to cite this paper: Canzano, A. (2019). The Paths of Islamism in Contemporary Islam: A Theoretical Re-Analysis. Advances in Applied Sociology, 9, 331-349. https://doi.org/10.4236/aasoci.2019.98024

Received: July 1, 2019

Accepted: August 4, 2019

Published: August 7, 2019

Copyright $\odot 2019$ by author(s) and Scientific Research Publishing Inc. This work is licensed under the Creative Commons Attribution International License (CC BY 4.0).

http://creativecommons.org/licenses/by/4.0/

\section{(c) (7) Open Access}

\begin{abstract}
This article analyzes the complex relationship between Islam and the West. Through the various authors who have made important contributions on the subject we will try to retrace the most important theoretical steps that are at the basis of the relationship between Islam and the West. It starts from the alleged clash of civilizations to understand how the idea of the enemy is often inherent in this relationship and how the irreducible Islam politicity caraterizes a certain tendency towards Islamism of which Salafism is the highest representative. Violence and terrorism find space in this drift; for relevant sectors of Islam, the world jihâd is an essential necessity.
\end{abstract}

\section{Keywords}

Islamism, Theories, Violence, West, Conflict

\section{Introduction}

The choice of the topic dealt with, responds mainly to the need of reaffirming some useful fundamental concepts as instruments of interpretation and understanding the current phase of confrontation and clash already present with Islam in our societies.

In the age of Islamism, arguably, the revival of this wide segment of Islam, which threatens the world order and security through various forms of militancy, needs to be re-analysed in order to try and re-establish the right theoretical terms in an often confusing and manipulated debate. 18 years after the terrorist attack of $11^{\text {th }}$ September 2001, the world jihad has intensified to such an extent that it is now the greatest threat both within Muslim countries and the international community. Terrorism is too often confused, both lexically and conceptually, with related but not comparable phenomena, such as fundamentalism, Islamism and in some ways, Islamic radicalism. Some of these phenom- 
ena can encourage terrorism in some cases, for example preparing "minds" for action, and can also be a major source of recruitment in others. However, Islamic terrorism is a phenomenon which must be analysed on its own, and what we are interested in here is reviewing its premises from a theoretical point of view.

First of all, unlike what occurs in common language, when being strictly scientific we should be careful not to confuse the two adjectives "Muslim" and "Islamic", with the former meaning the general believer-who often only formally follows religious precepts - and the latter referring to the militant who fights for the affirmation of Islam not only in a religious but also in a political context. Likewise, the distinction should also apply to "Muslim culture", which is a merely sociological definition, and "Islamic culture", which includes more ideological and political references (Guolo, 2007: p. 104).

A similar distinction must be made between the terms "Islam" and "Islamism", which are often wrongly used interchangeably. Indeed, even if Islamism is an aspect of the Muslim religion as a whole, it cannot be simply attributed to the latter, nor associated with it.

Islamism, or political Islam, is rather one of the political-religious movements that have "cyclically" emerged throughout Muslim history, claiming the monopoly of the orthodoxy of this religion, which pays the price for the lack of unanimously recognized guardians of its dogma. In this sense, Islamism aspires to a real "Muslim redemption", if possible, through a universal and all-encompassing conception of Islam only, thus finding a remedy to this "religion without a centre" (Guolo, 1999: p. 10).

Indeed, the Islamist collective action is primarily based on the classic principles of inerrancy of the sacred text, according to which the saving message is to be received in its integral form. The Word cannot therefore be reinterpreted in a particular historical perspective, nor can it be adapted to the changing social contexts. Hence, the Word is not only ahistorical, but it is also beyond history, transcending it. For this reason, Islamism adopts the idea of the superiority of the divine Law over the worldly one and, consequently, tries to reaffirm the myth of the foundation, that of the "City of God" founded by the Prophet, in which Islam was an all-encompassing and at the same time closed system summarising in itself religion, politics and society.

Given these premises, it is not surprising to see Islamism gaining ground in the political sphere. Indeed, it uses the classical religious categories of the Muslim thought as instruments to legitimise its political and social opposition to what it defines as the "regimes of cruelty", adopted in the religiously unlawful Muslim states. Hence, the aim of Islamist groups is to re-islamise Islam and modernity as well. They deny that contemporary Muslim societies are genuinely Islamic, and are firmly opposed to the previous reformist attempts which emulated the West in order to modernise their world.

A theoretical re-reading of the phenomenon is necessary in order to reiterate some key concepts clarifying misleading clichés, and to account for an evolution 
which is currently concerning Islam and its relationships, arguably, with the rest of the world.

\section{The "Hostile" West}

A theoretical re-reading of the Islamic phenomenon cannot take place without taking note of three classical authors, who significantly contributed with different approaches to shed light on a phenomenon which is at the moment the greatest concern for global security.

In the mid-1990s, Samuel Huntington, taking up some of Arnold Toynbee's assumptions, had already focused on the concept of a universal civilisation with a "radioactive" potential and characteristics able to trigger adverse and defensive reactions, of which the Islamic rebirth, in some of its forms, is among the proudest.

The appearance of a universal civilisation represented by the West is essentially due to the development of the modernisation process which, in its various forms, establishes itself as a culture capable of describing civilisation as a whole. Specifically, we are talking about an "extended order of civilisation" based on a "cultural evolutionism" whose main principles are represented by a "new morality". The latter is described as a process of transmission of habits, customs and rules interactively established between reason and civilisation, which allows us to speak of a real co-evolution. As a result of this, an extended order, or market order, has been established, defined by Hayek as "catallaxy", which is capable of describing a free, pluralistic and potentially borderless society. The universalistic aspect is embodied in the concept of "catallaxy" as economic order, which not only knows no geographical barriers, but also gives an idea of an inclusive community overcoming every form of division, a community that Hayek calls "great society". The catallaxy universalism has its own and exclusive characteristics which make Western civilisation irreconcilable with some and incompatible with others. The most important characteristic is individualism, which has allowed more than anything else the establishment of the Western economic and social order, identifying the primacy of the individual as the social paradigm to which all forms of interaction are subject. Individualism is the product of the Western cultural evolution which is more in contrast with the cultural expression of other civilisations, such as the Islamic one, which is based on collectivism. Individualism is connected with the state of law and social pluralism. The former, as a particular form of evolution of the civilisation of law and meant as "rule of law", is aimed at establishing the equality of all individuals before the law and the exaltation of individual freedom by reducing the powers of the State. And the latter as a form of evolution of social relationships is intended as a guarantee of free competition for individuals and groups and is aimed at pursuing the most diverse purposes in every social field. At the political and institutional level, the evolution of representative bodies, as places of formation of the general will, has allowed the West to stand out from a democratic and proce- 
dural point of view as a civilisation where the autonomy of politics and the civil sphere prevails over the religious sphere, which is relegated to an intimate and private dimension. The combined presence of these characteristics makes the West a unique civilisation, capable of universally embodying and representing the idea of modernity and of guiding its process worldwide.

There have been very different reactions to the Western universalistic claim: the one we are interested in here is the rejection reaction, which has led to a double behaviour for the law of contraposition: one which, against that of the West, is expressed in terms of an external conflict aimed at hitting the "enemy" and one internal, against those who do not want to recognise and fight the enemy or do not do so adequately.

The nature of this double conflict is very different from that of the past. It no longer has ideological roots related to the dynamics of the Cold War, but has turned into an ethnic-identity and cultural conflict in which religion plays a major role, as in our case. We might have reasonably thought that the advance of modernisation in non-Western countries would lead to higher levels of laicisation and secularisation. On the contrary, as in the case of Islamic countries, we have witnessed a revival of the religious sentiment. It means that, on the one hand, westernisation is absolutely unable to self-establish worldwide in the absence of a specific and spontaneous cultural evolution and that, on the other hand, some consequences of modernisation may cause identities to become more rigid and religious belonging to be shown off, sometimes in conflicting forms. The religious movements, which are the protagonists of this reaction, are anti-secular and anti-universalistic and they are aimed at recovering the sacredness as the basis of social organization. The religious revival (Huntington, 1997: pp. 135-136) is a reaction to laicism, moral relativism and the need to re-establish a social order based on the strengthening of community ties.

Muslims usually tend to consider religion as a primary source of identity: it is Islamism and nothing else, much like nation or ethnicity, that provides an essential principle of collective identification (Ibid.). Moreover, loyalty to the religious community, which significantly contributes to the construction of the identity, is at the basis of the re-islamisation of almost the entire Muslim world and involves all social classes. Religious elites are playing an increasingly pivotal role in offering the inspiration and suggesting the direction to be taken to communities and States, placing religion as the starting point of all directions. The way Islamism has been establishing itself throughout the Muslim world and in the immigration of countries shows how occidentalism and its influence on the political, civil and moral life of Islamic communities are being strongly rejected so as to keep these communities safe from cultural relativism and moral degeneration. It is as if Islamism had decided to stand as a global leader of anti-westernisation, the Ayatollah Khomeini himself and, at the same time, as the solution to the evils it produces. "The Islamic Renaissance in all its breadth and depth is the last stage of the incessant process aimed at defining the relationships between the Islamic 
civilisation and the West, an attempt to find the 'solution' not within Western ideologies, but within Islam" (Ivi, 154/155). Islam as a solution refers to an idea of religion which includes every dimension of life and considers the religious community as the only place of development of the person, deprived of their individuality. Overall, the so-called "Islamic renaissance" (Huntington) consists firstly in the development of Islamism in the cultural field, and secondly in the social and political fields. And yet despite the attempts to stem it, the elites in the various fields had to accept and in some cases suffer the trend in place. For example, in the mid-1990s Islamisation already permeated the society and politics of most Muslim countries far more than in the recent past. If the Islamisation process has managed to assert itself so quickly and determinedly, it is due to the role played by the Islamic social organisations which have established themselves effectively in the fields of education, culture and social affairs, thus creating a sort of Islamic "civil society" able to overcome the fragile network of secular organisations and institutions. While asserting itself, Islamisation has also taken advantage of the adhesion of the growing urban proletariat, which has found within Islam an identity and a reason for dignity. Thanks to the acquisition of this important social class, the various Islamist movements were sometimes able to stand as interlocutors and more often as the only opposition and political alternative to the national governments. Many governments experiencing a crisis of legitimacy, as a result of this strength and its tendency to dominate society, have granted wide acknowledgements, thus contributing at legal and political level to the Islamisation process. Last but not least, Islamisation was also significantly aided in terms of influence and power by the so-called decline of the West (Ivi, 155/165).

\section{Islamisation and Politics}

If, as we have just seen, religion is the main vehicle of identity and if identity refers to the compliance with a comprehensive system of values, rules, guidelines, attitudes and behaviours, politics is an inseparable part of it. The Islamization in its most important features, is therefore a phenomenon that permeates society in all its aspects, making politics a dominant and an ineliminable part of it. The motivations are based on the essential feature that Islam does not admit to cultivating theological sciences: "God is one and transcendent 'there is nothing like unto him', (Qu., Surah 42, 11); and He is the Hearing, the Seeing; 'He, God, is one'; God, the Eternally Sufficient unto Himself, and none is like unto Him" (Qu., Surah 112, 1-2-4), and this is why He cannot be studied. Actually, despite their increased role in this field theological studies have never succeeded in modifying the structure of a religion, which is mainly based on a doctrine of ethics and conduct. Notwithstanding the presence of a sublime and perfect God, the transcendent aspect gives way to the centrality of orthopraxis and its systematisation (Campanini, 1999: p. 7). “... the Quran can be intended as a practice. It is not a simple practical guide for the organisation of individual and 
community life; it is the operational science of society since it is itself constituted through the real movement which [...] allows humanity and each single man to recover their authentic meaning. History has one meaning and one meaning only: the Quran [therefore] represents God's indications for making history" (Etienne, 2001: p. 37). It is not surprising that in the case of Islam, politics plays a leading role and prevails over the theological sphere, where politics and power tend to be brought back within the revealed law (sharî ah).

Given the difficulty of conceiving an Islamic theology tout court, we must point out that in the Muslim world, in contrast with the Western experience, speculations were directly stimulated by the need to solve legal and political issues after the Prophet's death. Since then, an idea of politics (siyâsah) as part of a broader religious concept has been historically established, along with the idea that the political organisation must follow the religious input. This should not lead us to think that there have not been forms of political autonomy or specific evolutions in the relationship between temporal and religious power, as in the case of Sunni Islam. Although all the theorists of Islam agree in saying that the siyâsah should be inspired by the sharî ah, not all of them, however, share the idea that the siyâsah should follow the sharî ah blindly, with the latter being the main inspiration of politics within which it is possible to predict and find an area of autonomous intervention. The fact that the term siyâsah is not in the Quran, yet contains different interpretations within the various currents of Islam, does not imply a division between politics and religion. The "render to Caesar the things that are Caesar's; and to God the things that are God's" (Matthew 22, 21) as the first form of recognition of a power other than the one originating from God cannot be contemplated. Indeed, "Essentially, the Prophet's mission consisted in the transmission of God's message and, consequently, in the appeal (dawa) launched in his favour to gather as many believers as possible. The power (Mulk) is therefore represented by the duty to provide the Ummah with a temporal organisation on the basis of this appeal, in order to lead it to salvation. The community leader receives the imperative mandate to achieve the aims of this temporal life for all men" (Ibid.). The Islam rules of social living are well justified only if they are related to the indications of God, and the word of God is constantly addressed to the social whole, thus favouring an unequalled statutory basis. From this point of view, law and politics, more than theology, are at the basis of Islam and determine its direct application in the social sphere. In the Muslim world, as Choueiri states, science of religion is both a science of God and a science of the community, of the earthly city and its set of rules: a political theology which has the law as its concrete object [...]. Rather than a union of politics and religion, he would speak of law as a "hinge" between theology and politics and, at the same time, as a system of self-limitation of the scholars' (ulamâ) hermeneutical possibilities in sacred things and as a supreme guarantee against any form of usurpation of power or exercise of politics in contrast with the Quranic Law (Choueiri \& Pace, 1993: p. 12). “Obey God, and obey the Messen- 
ger, and those in authority among you" [Qu., 4, 59]: the Islamic thought is therefore strictly based on ethics and politics.

Only after reaffirming decisively that Islam is a religion mainly based on ethics and politics, can we discuss the relative autonomy of politics, specifying that it is a form of autonomy which proves not only the possibility of freeing politics from religion, but also the possibility that politics and religion may not coincide completely. What's more, even when they do not coincide perfectly, the general inspiration to the basic principles of social organisation is always in the background. The birth of most of the contemporary Muslim states of the $20^{\text {th }}$ century established the separation between the political and religious spheres in an informal and compromising way, in which the religious sphere, institutionalised in the system of the ulamâ, does not hinder any form of government, provided that it is not in conflict with the Quranic law and does not violate their traditional privileges. With the exception of pre-Erdoğan Kemalist Turkey and for various reasons Khomeini's Iran, most Muslim countries had Islam as their official state religion and Islam as religion of the head of state.

With the birth of these States in the $20^{\text {th }}$ century, the modernising Muslim elites aimed at elaborating, by taking into account the intrinsic limits of the sharîah, a more complete theory concerning the autonomy of politics, and so trying to reduce the influence of religion on the State affairs in the civil and criminal spheres, in educational policies, etc. ... The underlying themes were modernity and the consequent solutions to be adopted in order to make a state modern in political, economic and financial terms, and in the legitimation of leadership (Ibid.). It was a real secularisation process of Islam, meant as a "secularisation from above", which started more or less in the 1950s and took two different paths to impose itself: one "outside religion", or breaking the relationship with the pre-existing religious tradition, was embodied by Kemalist politics and later imitated by the Syrian and Iraqi $B a$ 'th parties; and the other, coming from within Islam, was supported by all the reformist elites who tried in North Africa and in the Indian sub-continent to renew the religious traditions, adapting them to modernity (Pace, 1999: p. 13). The two external attempts of secularisation were different but both failed. Kemalism is now present only in some minority political groups and can no longer represent a political tradition able to become a majority once again in society and politics. The re-islamisation seems unstoppable and Erdoğan's Turkey can now be considered as a regime with authoritarian characteristics. The latter suffered a rapid decline following the overthrow of the Iraqi regime and the Syrian civil war, while the Egyptian socialism started by Nasser does not seem to have heirs today after the Arab Spring and the subsequent military coup d'état. This relation is mainly aimed at analysing the development of the reform attempt within Islam, and even though we cannot take into consideration the dense history of all the reform movements, we will try to give a general outline. The main characteristic of the reformist movement is its political-social nature, which arose in response to the Western 
supremacy and expansion. Islamic reformism emerged for the first time during the $19^{\text {th }}$ century under the pressure of many external factors to which it reacted in a very different way from the previous movements of the Islamic revival, thus generating several important political groupings.

Indeed, during the 1800s, many religious and political Muslim leaders began to notice the progressive decline affecting, above all, the Islamic societies which were more exposed to comparison with the Europeans. As a matter of fact, the Western financial, military and industrial penetration had significantly contributed to changing Muslims' intellectual perspectives. If it is true that the Islamic world had already suffered defeats and that its territories had already been occupied by foreign forces, it is also true that never before had the sense of decline and the consequent need to grasp the teachings of Islam's traditional enemies been so strongly perceived.

Therefore, the awareness of the decay became the privileged topic of the Islamic reformists' reflection: the normative Islam of Taymiyya and of Wahhah himself no longer appeared as the solution to the main problems of a social order which was already compromised. For the first time therefore, Islam was analysed and reconsidered under the watchful eye of a booming West, and the idea of Islamic self-sufficiency was definitively abandoned.

This new phase in the history of modern Islam was expressed by the Ottoman reform movement, the Tanzimat (reforms). The Tanzimat era started at the beginning of the $19^{\text {th }}$ century and initially introduced new administrative regulations only. They were conceived as modern and rational solutions aimed at helping a government practice that had become inefficient but was originally deemed valid. Later on, however, the reforms (islah), no longer limited to the administrative and military areas, extended also to the financial and cultural institutions, investing the political system as a whole (Guolo, 2007: p. 41).

More generally, Muslim reformism was represented by other currents of thought different to the rationalist ones which had been previously affirmed. Ultimately, while the Islamic revival considered Islam as a coherent dogmatic system whose foundations had to be rediscovered, reformism was more interested in material issues related, for example, to the Muslim military, technological and political backwardness.

The most respected current of reformism manifested itself within the broader movement of Ottomanism, which brought together young exiled Ottoman intellectuals, such as the Persian rhetorician Dîn al-Afghânî, the Egyptian spiritual master Muhammad 'Abduh, the Indian aristocrat Ahmad Khân and the Tunisian statesman Khayr al-Dîn Pasha.

All these people believed that the reforms could not be separated from the renewal of political institutions and from the acquisition of elements of modernity that went beyond technology: the intervention of a clever governor, assisted by wise administrators, was therefore necessary in order to reconcile Islam with modernity. Indeed, the institutional reforms proposed by reformism were aimed 
at limiting the absolute power of the sovereign, since-it was unanimously agreed-the decadence of the Islamic world was essentially due to the so-called "oriental despotism" (Ibidem). In view of this aim, reformists started reinterpreting the classical categories of the Islamic thought in accordance with the keynotes of the European debate of the period. For example, in order to legitimise the principle of power sharing, the exponents of this movement rediscovered the practice of shurra (consultation), which the Quran prescribes to believers as a deserving activity, thus transforming its meaning in terms of "political consensus".

Therefore, according to the reformists, it is through the institutionalisation of this practice in the political sphere that the action of the prince can find necessary consensus (ijmâ), although this practice-as the reform exponents affirm-should not be extended to the whole community, but only concern a small group of men closer to the sovereign.

These thinkers remained firmly opposed to the introduction of representative democracy, reaffirming the validity of the shûra as a compulsory consultation between the sovereign and a group of officials and advisers (Ivi, 43).

The reformism thus reveals itself as "a sort of Islamic constitutionalism", but without the capacity to operate and make innovative proposals at institutional level. Criticism against the autocracy of the time is limited to the theorisation of the right to consultation. The State is still distant and different from the Ummah, proving that political Islam is based on the idea of justice and legitimacy while remaining very far from the concepts of representativeness and sovereignty.

As for the ummah, reformism also focuses on the theme of the unity of the community, with its historical division perceived as a contributing cause of the decline of the Muslim world with respect to the West. The call for unity of the ummah finds in Rashid Ridâ its most tireless defender. A devout traditionalist, he supports the revitalisation of faith, now reduced to a religious ritual, as the keystone of the Muslim rebirth. His movement-Salafism-believes in a purified Islam, cleansed of superstitions and popular beliefs, following the Hanbali thought influenced by Taymiyya himself. Religion is conceived by Ridâ not only as a source of progress, but also as a "social doctrine" merged with the "sacred". Islam, therefore, is not a mere religion (dîn). On the contrary, it is the heart of the Islamic civilisation itself, based on a coherent set of rules, values and practices, capable of activating development in the entire community. The Salafists propose a model of modernity other than the western one, based on the reconstruction of the believers' community through the re-establishment of the caliphate.

The latter is, in fact, the original model adopted by the "rightly guided", which must be proposed again in the present through the application of the ijtihâd ("interpretative effort" of the Religious Law), an instrument capable of supporting at best the historical institution in its adaptation to the needs of modernisation. 
According to Ridâ, it is the ummah that must appoint through its consent (ijmâ) the caliph, supervise his work and even dismiss him, in the name of the common interest (Choueiri \& Pace, 1993: pp. 68-73).

However, the project of the different reformist currents would have to deal with the acceleration imposed by the progressive crisis of the Ottoman Empire. Between the end of the $19^{\text {th }}$ century and the beginning of the $20^{\text {th }}$, the Young Ottomans were gradually replaced by the Young Turks, radical intellectuals and army officers with a secular education, who became strong supporters of doctrines such as liberalism, secularism and popular sovereignty, thus abandoning all reference to Islam in political terms.

This school of thought, further consolidated by the abolition of the caliph by Mustapha Kemal Atatürk in 1924, became the protagonist of the political debate, and reformism, with its attempt to interpret religion in a modernising sense, gave way to new "westernising" doctrines, according to which Islam from then on, would be relegated to a mere private matter.

However, in the wider Muslim world and in the communities both inside and outside the Ottoman world, the affirmation process of this specific reformist current was very tortuous and mostly impracticable. In Iran, for example, religious leaders were firmly opposed to the idea of adopting a representative political system, claiming a much more limited form of consultation, such as an assembly of religious experts, with the task of judging the compatibility of the legislation with the Islamic precepts.

The Shiite clergy would not regret the end of the "constitutional revolution" of 1906, imposed by the Russians who were helping the rulers and aimed at strictly limiting the prerogatives of the Shah. "The attitude of Iranian Islam-Guolo concludes-is clear: the Muslim masses have nothing to do with the Western political culture. While easily circulating in large urban centres, westernising ideas such as liberal constitutionalism are not welcome in the vast countryside of the Fertile Crescent countries" (Guolo, 2007: p. 55). Therefore, it would be the crisis of liberalism, unable to impose itself in the Muslim world, to encourage the arrival of much stronger ideologies-this time strongly undemocratic. Islamic radicalism on the one hand, in all its disruptive force, with the Khomeinist revolution leading the Shiite masses towards one of the most organic forms of fundamentalism and, on the other hand, the reformist evolution of Salafism, establishing itself in the Sunni context as the movement which would most completely embody the fundamentalist ideology between the end of the $20^{\text {th }}$ and the beginning of the $21^{\text {st }}$ century.

\section{Islamism as a Response}

Through the evolution described, fundamentalism asserts itself in all its potential and ability to spread throughout the entire Islamic world, becoming the most important ideological-political phenomenon within Islam, making Islam the most seductive response to the problems of the Islamic world as we are going to 
analyse.

For Islamism, in order for a power to be defined as Islamic, it is not enough for it to be based on the legislation derived from the shari ah. The mere formal application of the Religious Law-as often invoked by the traditional fundamentalism of the ulamâ-is enough to change the "inauthentic" characteristics of society. The sharia can only be truly effective after the State and society have been purified by the collective Islamic mobilisation (Ayubi, 1991; Roy, 1992).

The reference to authentic Islam, as well as the union between the reinterpretation of religious traditions and political practice, makes Islamism a "fundamentalist" movement, with all the reservations that this term-so abused in media language-implies.

Youssef Choueiri himself, who entitles his essay on Islamist movements $I s$ lamic fundamentalism, admits from the very first pages that he used this expression "in the absence of a better term-and [in any case] with a more precise meaning-that would synthetically refer to a plurality of Islamic movements. These movements are very different from each other but they all concur that each one in the different historical periods-reformists, traditionalists, conservatives and radicals - has seen in the Quran the source of awakening of an Islam in decay and the solution to the social and political evils of the Muslim world.

At this point, we must identify the three priority objectives that Islamism pursues in order to save Islam from what it feels to be decay and subordination to the West:

1) Going back to the full application of the shari ah;

2) Recomposing the political-religious unity of the Muslim world through the refoundation of the caliphate;

3) Spreading Islam worldwide.

Indeed, Islamism does not want to be just a local geopolitical factor: it has world ambitions and breaks onto the global scene as the last "universalist" ideology, simplifying in a new bipolar scheme all the other affiliations. The world is thus divided into two great realities: the party of God and the party of Satan. The former includes the authentic believers; the latter the enemies of Islam, whether they are Western or the "false Muslims": in this way, the jihâd becomes an obligation of faith. Islam has therefore definitively turned itself from a religion into a totalising ideology (Guolo, 1999: p. 11). All this is exemplified by the story of the bigger and more important Salafist movement that played a pivotal role in inspiring and organising the global re-islamisation.

Indeed, the first movement which tenaciously proposed, in the last century, the theme of political Islam was the Muslim Brotherhood-al Ikwhan al Muslimun-founded in 1928 in Egypt by Hasan al-Bannâ (1906-1949).

Taking inspiration from the organisation of the Sufi confraternities, al-Bannâ created an articulated and distinctly hierarchical political-social movement-divided into cells and including also a military arm-initially influenced by Ridâ's Salafism. 
The corruption of Islam was deemed as the main cause of the decline of the Muslim world. Its moral and social purification through personal re-education first was therefore necessary.

During the 5th Congress, al-Bannâ broke with Salafism, proposing the new ideology of the movement, according to which Islam had to become both a global vision of the world and a universal religion.

The slogan of the Brotherhood "God is our objective, the Quran is our constitution, the Prophet is our leader, the struggle is our way; the death for the sake of God is the highest of our aspirations", says a lot about the nature and intentions of the movement. Indeed, if it is true that the ideology of the Muslim Brotherhood has some similarities with Muslim reformism, and in particular with the Salafism from which it derives, in which both are united by the need to return to the Sources and the criticism of the religious power, it is also true that reformism will always only remain a current of thought. On the contrary, with the Muslim Brotherhood we can see the definitive passage from theory to practice.

According to al-Bannâ-we can read in his message at the V Congress-Islam contains "everything concerning man in this world and in the other, and those who believe that these teachings only concern the worship or spiritual aspect, excluding the others, are wrong. Islam is belief and cult, homeland and citizenship, religion and state, spirituality and action, book and sword. The noble Quran talks about all this, considers it as an integral part of Islam, and recommends that it be applied fully" (Carré \& Michaud, 1983).

The Brotherhood leader goes on to say that the Islam of the Muslim Brotherhood represents a total concept, of universal scope, which will have to govern all aspects of life [...], if the nation wants to be authentically Muslim. But if it is Muslim in worship only, otherwise imitating other models, this nation is outside Islam. Bearing a totalising ideology, the Brothers define themselves not only as a movement of "return to the Sources" and "spiritual reality", but also as an "economic structure $[\ldots]$, social doctrine $[\ldots]$ and political entity, claiming "the purification of power" in internal affairs, and the "Pursuit of the interests of the Muslim nation" in foreign affairs (Ibidem), while not directly granting themselves the political power.

In fact, the organisational form of the movement will never be made explicit. However, it is undeniable that the Brotherhood acted as a real political subject. Nor will the Muslim Brotherhood ever speak of the establishment of an Islamic state, but only of an "Islamic order". However, this sort of refusal to directly manage power seems to be linked more to the unfavourable historical circumstances in which the movement has to act, than to a position of principle (Guolo, 1999: p. 18). Indeed, when circumstances in Egypt allowed it, both during the 1952 revolution, of which they constituted the social basis without being able to assume leadership (where Nasser's nationalism would prevail), and following the Egyptian Arab Spring, the power was evoked and in the latter case obtained, as 
shown by the personal and political story of Mohamed Morsi, leader and president of the Muslim Brotherhood, who was later dismissed after the military coup d'état by Abd al-Fattāh al-Sīsì.

\section{Abû'l-Alâ Al-Mawdûdî and Sayyid Qutb: Criticism of Democracy and the Foundation of the Islamic State}

For Islamism, as we have mentioned, the form and organisation of power are not indifferent and we could say that regimes are not equal in the eyes of God. Indeed, there is a concept which is challenged by Islamist political theorists, maybe more than any other: democracy. Democracy is considered as a real disvalue because, by deriving power from men rather than from Revelation, it constitutively denies any direct reference to the authority of God $(h u k m)$. Democracy is therefore rejected because it questions the sovereignty of God (hâkimiyyyah), replacing it with the notion of popular sovereignty (Campanini, 1999: p. 247). Islam, on the contrary, is in contrast with the Western democratic tradition and its institutions, referring to the idea of tawhid, the principle of divine oneness wherein: God is unique and cannot be compared to anyone, while democracy, exalting the role assumed by the sovereign people, makes it a "new divinity", thus creating, for this very reason, a dangerous "association" with God. The Islamist theorists then oppose democracy to the precepts and dogmas of Islam, considered as a source of inspiration for human behaviour in every field. Islam, in fact, is not only a faith, but also an "ideological state", a whole and complete system of life.

It has already been said that for al-Bannâ, interpreter of an exciting and a-historical reading of the Quran, Islam was both spirituality and action, book and sword. However, if with the Brotherhood it is still difficult to define the form that power must assume, this is no longer an insurmountable problem for the two main theorists of Sunni Islamic radicalism: the Pakistani Abû'l-Alâ al-Mawdûdî (1903-1979) and the Egyptian Sayyid Qutb (1906-1966).

As a matter of fact, they were the first to theorise the creation of the Islamic State, founded on the following cornerstones:

- The principle of divine sovereignty (hâkimiyyyah);

- Institutionalisation of the consultation system (shûra);

- The conferral of power to a charismatic leader with the dual function of spiritual and political guide of the ummah;

- The limitation of human interference, through a double channel of control constituted by the integral application of the shari $a$ on the one hand, and by the search for the consent (ijmâ) of believers' communities on the other.

The theorist who, since the 1940s, has reflected the most upon the Islamic State is Abû'l-Alâ al-Mawdûdû, founder in India of the association Jamâ at $i$-slâmî for the Propaganda of the Faith, and creator of the Islamic separatist movement that gave birth-in 1947-to Pakistan. He was the one who forged the political vocabulary of radical Islamism, introducing, among other things, 
the term hâkimiyyah, in which sovereignty belongs exclusively to God and the integral application of the shari ah cannot be the logical consequence of this acknowledgement. The mistake of men, on the contrary, has been to arrogate sovereignty to themselves, while they should only be allowed to obey the one "Lord of the world". According to al-Mawdûdî, this fundamental right-duty expresses the maximum freedom of God's subjects, given that there is no freedom in human behaviour that does not perfectly correspond to the commands of the divinity. Taking the criticism of the traditional quietist theses of the long Tradition of Islam to its extreme consequences, the Pakistani ideologist goes so far as to consider illegitimate any power that is not based on the sharîah, just as those Muslims-not Islamic-guided by rulers who apply human laws instead of the religious ones-come to be without authority. The only exception to this basic principle is the possibility of intervention by the legislature to the extent that, in a particular discipline, there is no rule explicitly given by God or in any case deduced from the prophetic Sunnah. Only in these unique cases is ummah given the right to fill, on a consensual basis, the existing regulatory void, provided that human legislative activity does not violate the precepts contained in the Religious Law.

In this sense, Islam-according to al-Mawdûdû-is the only true democracy, and the caliphate its area of application. On the basis of Rashid Rîdâ's thought, the Pakistani radical relaunched the idea of the caliphate as a centre of political reorganisation of the ummah but, since the human being can do nothing without divine guidance, the caliph is still a mere "business manager", whose legitimate owner is God (Guolo, 2007: p. 61). The Islamic prince, chosen on the basis of his management skills, but also by virtue of his piety and knowledge, would therefore be constantly controlled by the shari ah and by a special consultative council (shîra): in the Islamic State there would therefore neither be elections nor freedom of association. Indeed, it represents a political system that institutionalises party competition whilst being in contrast with the two fundamental principles of equality of believers and divine justice: these, in short, are the essential characteristics of the theodemocracy designed by al-Mawdûdî. However, the character who still has the greatest influence on the radical groups of Islamism is Sayyid Qutb, already a leading ideologist of the Muslim Brotherhood, then imprisoned and sentenced to death by Nasser.

In his two main texts-Fî Zilâl al Qư' ân (In the shades of the Quran) and AI Ma' âlim fi $t$ (Milestones), Qutb reconstructs in depth the whole Islamist ideology, starting from the redefinition of the key concepts of the Islamic political thought, among which those of ignorance (jâhiliyya), rupture(hîjrâ), struggle in the way of God (jihâd) and revolution (thawra) (Carré, 1984) particularly stand out.

Going by order, we must immediately point out that in the Quran the term jâhiliyya marks the period of ignorance in which the Meccan population existed before the Revelation. Qutb, on the other hand, expands this word turning it 
into a real hermeneutic category, meaning everything that is foreign to Islam, in the present as well as in pre-Islamic times. "everything around us is jâhiliyya-he maintains-people's conceptions, their creeds [...], their art and literature, their laws and constitution; even what we are used to considering as Islamic education [...] is the product of jâhiliyya" (Qutb, 1981: p. 21). Hence, in the Egyptian ideologist's dichotomy, there are no other types of intermediate societies than the Islamic and the jâhiliyya ("ignorant") societies, irreducibly opposed.

The cause of man's moral degradation in the contemporary societies of error is to be found, according to Qutb, in the opposition to God by men who, unable to interpret the divine message, replace his worship with that of false idols, for example trusting in human sovereignty. "Islam, on the other hand", he says, "is a declaration of war against all human power [...], a conflict that is open wherever there are men arrogating power to themselves [...]. Every system in which the final decisions are delegated to human beings [...] is, in fact, a form of idolatry, since it identifies some people as lords in place of God (Ibidem)". On the contrary, the rebirth of the Islamic world can only take place starting from the full understanding and militant adherence to the dynamic sense of the sacred text: Islam-in Qutb's opinion-is, in fact, "a dynamic method of life that only militants and fighters can truly understand and interpret". It is their duty, therefore, to firmly oppose the decadence of the world, taking inspiration from the Medinese period of the Prophet's preaching, whose main concern was to build Ummah after affirming that it is the best that God has created on earth. If, in fact, during his Meccan preaching, Mohammed speaks to the consciences of individuals, announcing the omnipotence of God and mercy towards those who repent, once he arrives in Medina he insists on the theme of divine punishment against those who do not fight for His cause. The Quran explicitly says: "Fight those who do not believe in God or in the Last Day [...] and who do not adopt the religion of truth from those who were given the Scripture" [Qu., surah 9, 29]; "Fight them until there is no fitnah and [until] the religion, all of it, is for Allah [...]" [Qu., 8, 39]; "O believers! Fight the unbelievers who are near to you! And let them find in you a harshness" And know that God is with the Godfearing!" [Qu., 9, 123].

The basic elements of the Medinese community are therefore two: the rupture (hijrâ) with the impious meccan environment, and the struggle in the way of God (jihâd).

Qutb takes up these two elements, with the intention of putting them into practice in two consecutive phases: "the task of promoting the resurrection of the ummah belongs" [in fact] to a "vanguard that must resolve to set it in motion in the midst of jahiliyyah". This vanguard must be able to put into practice, as the Prophet who escaped from Mecca to Medina, both the rupture and the "contact" with the surrounding jâhiliyya (Guolo, 1999: p. 25). In the end, the Islamic vanguard movement the ideologist refers to would have to constantly fight against the jâhilite society, forcing all its members to take sides. However, the 
battle Qutb speaks about is the jihâd in its double meaning-moral and political at the same time-of "spiritual effort", by the believer who sincerely approaches the faith, and of "struggle in the way of God".

The revolution (thawra) of the soul, therefore, is absolutely inseparable from the real armed struggle for God. "This struggle [...] is a practical way to test one's role after testing the soul, in order to purge the nation of defeatists, saboteurs and propagators of falsehoods". "The jihâd [then] is not to be intended as a defensive action", in the specific sense of "war of defence". Instead, it is a movement for the freedom of man on this earth that makes use of all the necessary means, according to Sayyid Qutb (Qutb, 1981: p. 65).

As we have just seen, he rejects the minimalist interpretation of jihâd as a means of defence; the Qutbian fight is, indeed, maximalist and aggressive.

In this sense, the ideologist even opposes al-Mawdûdû, according to whom "God [...] has prohibited us from bloodshed without necessity [...]". His order is to fight only against those who first use weapons.

Qutb, finally, rejects the traditional geopolitical and religious dichotomy of Islam, which, from the beginning, divides the world into the House of Islam (dâr al-Islam) and the House of War (dâr al-Harb), an expression by which Muslims indicate everything that is outside their own space and, in particular, the West.

Indeed, between these "two houses" there has historically been hostility, but also truce and coexistence.

For Qutb, on the contrary, this division has become obsolete, as well as static, and could be abolished, with the enemy now being within the Muslim world and the West is now the internal West.

Hence, there are only two parties left, within which all the more circumscribed affiliations fatally fall: the party of God and that of Satan. However, since the fight against Evil inevitably has a global scope, then the war planned by Qutb cannot but take the form of a new global war-a war of religion, led by radical Islamism.

\section{Conclusion: The jihâd against the Crusader West}

In conclusion, after analysing the development of Islamist fundamentalism in its main aspects, let's see what its main consequences are.

For the radicals therefore, Islam and jâhiliyya are the only two authentic interpretative categories around which all the historical groups gather.

Qutb states, indeed, that outside of the Ummah there is only one great Jahilist party-or Satan party, as we have seen-composed of "human demons, crusaders, Zionists, pagans, communists, who join together in order to crush the vanguard of the movements for Islamic rebirth throughout the earth" (Qutb, 1981: p. 1208).

The theodicy of Islamism therefore, is configured as a relentless hostility towards those who do not recognise themselves in the party of God: it is a double war, both internal and external, against the powers of Evil, represented by the 
impious Muslim rulers on the one hand and by the West-but also by world Zionism-on the other.

Starting from the Qutbian ideology, the Islamic radicals have proclaimed the jihâd against the false Muslim rulers, bearers of a secular and at the same time nationalist thinking, which encourages the penetration of Western culture into the countries belonging to the House of Islam. Overall, this is how the fight against them is legitimised.

For many Muslims, in fact, the West is responsible, through the imposition of the experience of modernity, for the state of decadence in which the ancient community of the Prophet finds itself today, disappointed by a modernity to which they cannot fully gain access. The refusal of the West, a real disease for Islam, thus becomes an instrument of collective redemption.

To the Western intoxication, Islamism opposes an image of Islam that cannot be traced back either to a mere theological opposition, nor to a simple cultural diversity. Such imagery, in fact, expresses itself-once again-at political level, constituting a real system alternative. The West is therefore seen as the great Satan who opposes Islam in the competition for world leadership. In this sense, the medieval definition of the "Crusader West", which recalls the Christian holy wars against Muslims, seems to effectively represent the current religious clash of the radicals against the Western enemy. The Islamists talk about a world conspiracy of the West against Islam, which has assumed various connotations over time.

The Western world is accused, first of all, of having historically caused, through colonialism, the division of the original ummah into many nation-states. In addition to such division, which prevents the Muslim community from recomposing itself globally, the Westerners are also guilty of perpetuating their domination through cultural penetration, imposing its affirmation among the impious Muslim governors. The return of part of the Muslim world to Islam as a religious and political response to secularisation is of course explained well by the unfortunate results of the modernisation process promoted by many Muslim countries led by secular, military or nationalist leaders. The political, economic and social structures of the new Muslim states have often failed to cope with the impact of progress: "the particularities of the new ruling classes, the growing economic difficulties [...]". The rapid and devastating urbanisation [...], have resulted in the breaking of traditional social ties, very high rates of population growth, and a widespread phenomenon of rejection of everything that is West. Hence, we are witnessing a process of "re-traditionalisation" caused by an excess of modernity (Guolo, 2007: p. 97). In particular, "the recent phase of [economic and cultural] globalisation has further reduced the space-time distances, increasingly turning the world into a global society and making it [consequently] more and more difficult to remove Islamic culture from the influence of Western culture [...]. The West is more than ever represented as an actor of the Islam perversion; as a destructor of the Islamic identity" (Ibidem). The West 
is therefore accused of constantly undermining the unity of the Ummah, with the participation of all Western countries.

In this case as well, the political-theological hostility of radical Islamists towards the West is strongly influenced by the Qutbian theories. Indeed, according to Qutb, the evil nature of the polytheistic West (sirk) lies in the initial theological error of Jews and Christians, who refused to recognise the saving message of the Prophet. The Jews would thus be responsible for breaking the original pact made by Abraham with God, "ethnicifying the divine message in their own favour and constituting themselves as a separate people". The Christians, in turn, would be guilty of "betraying the announcement of the message, separating law and ethics, power and religion, breaking its intrinsic totality" (Guolo, 1999: p. 70).

Hence, after rejecting Islam as the Seal of Prophecy, "both Christianity and Judaism-Qutb says-are no more than false religions" (Qutb, 1981: p. 1891). It is therefore right to undertake a total and uninterrupted war against them: the global jihâd, for the realisation of which the so-called Islamic internationalism started affirming itself in the ' 70 s.

It is a phenomenon in which groups of Islamic militants of different nationalities are engaged in the practice of the offensive jihâd, even outside the territory of their respective countries of origin, in order to keep alive the pan-Islamist myth of the ummah. The objective of the internationalist radicals is, in fact, to put the universalist ideology of the ummah into political practice. According to them, the breaking down of national borders, internalised by the community of believers over the centuries, becomes possible only if the fight is extended worldwide. Hence, in addition to the individual national jihâds, which allow the fight to be continued against the internal enemy of the regimes of impiety, there is also the global jihâd, whose aim is the liberation of the world in the dual meaning of defence and offence against "the enemy".

And it is in this meaning and for this purpose that the global jihâd takes on connotations of pure terrorism, of which all the Salafist organisations in the Middle East, in North and Central Africa, in Central and Eastern Asia, and in their European and world projections, are protagonists. And, if the fight must be undertaken everywhere and through any means, this only confirms that, for relevant segments of Islamism, the global jihad is an absolute necessity.

\section{Conflicts of Interest}

The author declares no conflicts of interest regarding the publication of this paper.

\section{References}

Ayubi, N. (1991). Political Islam. London, New York: Routledge.

Campanini, M. (1999). Islam e politica. Bologna: Il Mulino.

Carré, O. (1984). Mistique et politique, Lécture revolutionnaire du Coran par Sayyd Qutb. 
Paris: CERF.

Carré, O., \& Mishaud, G. (1983). Les Frères Musulmans (1928-1982). Paris: Gallimard. Choueiri, Y. M., \& Pace, E. (1993). Il fondamentalismo islamico. Bologna: il Mulino.

Etienne, B. (2001). L' islamismo radicale. Milano: Rizzoli.

Guolo, R. (1999). Avanguardie della fede. L'islamismo tra ideologia e politica. Roma: Laterza.

Guolo, R. (2007). L'Islam è compatibile con la democrazia? Roma-Bari: Laterza.

Huntington, S. P. (1997). The Clash of Civilizations and the Remaking of World Order. New York: Simon \& Schuster.

Pace, E. (1999). Sociologia delP Islam. Fenomeni religiosi e logiche sociali. Roma: Carocci. Qutb, S. (1981). Fî Zilâl al Qử ân. Cairo, IL: Dârash-Shûruq.

Roy, O. (1992). L’échec de I Islam politique. Paris: Seuil. 